\title{
Nature of Human Resource Management (HRM) practices and Its impact on Employee's Job satisfaction: A case study on Dutch-Bangla Bank Limited
}

\author{
Khadiza Rahman \\ Senior lecturer, Department of Business Administration, Stamford University Bangladesh
}

\begin{abstract}
In the recent scenario, HR practice plays a vital role in organization to increase the employee performance. This paper examines the Nature of Human Resource Management (HRM) practices and Its impact on Employee's Job satisfaction using data collected from Dutch Bangla Bank Ltd (DBBL)in Bangladesh. The study tries to determine the effect of training and development on employee job satisfaction; to determine the influence of working conditions on employee job satisfaction and to determine the impact of human resources factors on employee job satisfaction. The survey instrument used in the collection of data was the questionnaire. Almost 60 employees of the bank covered this entire survey of DBBL. It evaluates and compares existing human resources management activities of employee recruitment and selection, job analysis methods, performance evaluation, leave, promotion scheme, training and development programs of DBBL. The findings addressed meaningful situations which is imperative for employees and organizational growth and development of this bank. Thus, the recommendation will support proper implication of human resources management system in $D B B L$. Human Resources Management has an enormous upshot on employee job satisfaction. This is to advise for DBBL to develop good HR practice and it must increase more employee participation further. Today's business environment is much more dynamic and DBBL should take necessary steps to adopt strategies to motivate and equip their staff, so as to confirm their loyalty and be source of competitive advantage.
\end{abstract}

Keywords: Human Resource Management, Working Condition, performance evaluation, Job Satisfaction.

\section{Introduction}

Performance and productivity of an organization basically relies on the quantity and quality of human resources. Human Resource Management practices on employee performance has been an important area of research which indicates a positive relationship between HR practices and job satisfaction. The quality of the human resources can be improved through education, training and personal development and the quantity of Human resource can be improved through good and successful management planning and policies. Effective HR practices improve the performance of organization and lead to higher profits. HR practices has been an important and critical area in management and organizational performance from the last few years especially in the banking Sectors. The banking Sector, is one of the major segment of the financial system which plays a crucial and competitive role in the economic and social development of a country. In the competitive environment of modern era organizations are persistently improving performance of their employees by improving HR practices. Due to the dynamic and competitive nature of the banking environment, an innovative HRM practices have to focus on equipping employees with new and diverse skills, and also to ensure flexibility of employees so as to be able to respond to change. HRM practices need to consciously revolve around provision of issues that not only enhance job security but make the employee satisfied on the job with increased job security and satisfaction (Barrows \& Wesson, 2000). This derives from the fact that the best asset in an organization is the people, and not just people, skilled and competent people which need to be managed effectively to ensure job satisfaction. it also can be best achieved through recognizing and enhancing the human dignity of each employee. Happy employees are the Potentials employees and they are always productive. In previous studies, there are numerous research on the job performance, Performance appraisal, job satisfaction, Absenteeism and turnover are two variables which effect on job satisfaction (Steijn, 2002). Job performance appraisal relates to the job production and job productivity. Generally, high job satisfaction is connected with high productivity, low turnover rate and low absenteeism in the workplace with the production commitment and compromise (Hackman \& Oldham, 1975).

In this paper researcher investigates the effect of HRM practices in Dutch-Bangla Bank employee performances such as Training and Development; Staffing Level; and Working Condition, which form major concepts of HRM functions in the Banking Industry. In Bangladesh, commercial banking system dominates all kinds of financial sector and central bank of Bangladesh is the chief regulatory authority. The banking system is composed of six state-owned commercial banks, five specialized developments banks, eight Islamic Shariah based Commercial Banks, thirty-one private commercial banks and nine foreign commercial banks. In 
Nature of Human Resource Management (HRM) practices and Its impact on Employee's Job ..

Bangladesh, most of the human resources related decisions are mainly taken by the central management. In different branches these decisions are just implemented (Afroj, 2012). In order to achieve these research objectives, the paper reviews literature on HRM and Job satisfaction; Staffing Level and Job Satisfaction; Training \& Development and Job Satisfaction; Working motivational Conditions and Job Satisfaction.

\section{Objectives of the Study:}

The main objective of the study is to analyze the impact of HR practices on Job satisfaction of Dutch-Bangla Bank Limited

\section{Methodology of the Study:}

It's a descriptive study in nature. I have collected both primary data and secondary data for the study. I have collected their job satisfaction level regarding HR practices through a structured questionnaire. I have selected 60 employees through convenience sampling technique. Finally, I have analyzed the primary data through frequency distribution.

\section{Literature review}

HRM deals with the human side of management and enterprises and employees' relations with their organizations and its purpose is to ensure that the workforce of organizations are effectively and efficiently utilized in such a way that the employer obtains the greatest possible benefits from their abilities and similarly, the employees obtain both material and psychological rewards from the services rendered. Businesses are dependent on effective human resource management to make sure that they hire, train and develop good and effective employees and that they are able to respond to the grievances of employees in order to have some level of satisfaction on their jobs. Human Resource Management specialists determine the number and type of employees that a business will need over its first few years of operation. On top of that, they are responsible for staffing, which involves recruiting employees to occupy newly created positions and in some cases to replace vacant positions (Huselid, Jackson, \& Schuler, 1997). A division of HRM engages in training of its staff in order to encourage worker's satisfaction on the job (Laursen, \& Foss, 2003). Likewise, Human Resource Administrators implement and manage compensation plans and benefits packages for employees. Essentially, this aspect has been argued to be part of the substantive issues link with employees' dissatisfaction, if not timely and adequately addressed (Guest, 2002; Marchington, \& Zagelmeyer, 2005).

Human Resource Management is a set of interrelated policies with an ideological and philosophical underpinning and these policies are classified under four aspects vis-a-vis (i) constellation of beliefs and assumptions; (ii) strategic thrust informing decisions about people management; (iii) the central involvement of line managers; and (iv) reliance upon a set of 'levers' to shape employment relationship (Storey, 1989). The human resource management activities can be summarized briefly under five major domains: (i) organizational design; (ii) staffing; (iii) performance management appraisal; (iv) employment training and organization development; and (v) reward systems, benefits and compliance (Berdamine, 2004). The overall purpose and objective of human resource management is to make sure that the organization is able to achieve success through people (Armstrong, 2006). As illustrated in the literature, Ulrich and Lake (1990) argue that Human Resource Management systems can be the source of organizational capabilities that allow firms to learn and capitalize on new opportunities. However, as obtained in the literature, HRM is said to be concerned with achieving the following: organizational effectiveness; human capital management; knowledge management; reward management; employee relations and meeting various needs (Armstrong, 2006).

The management of people at work is an integral part of the management process. In order to understand the critical importance of people in the organization is to recognize that the human element and the organization are synonymous. A well-managed organization usually sees an average worker as the root source of quality and productivity gains. Such organizations do not look to capital investment, but to employees, as the fundamental source of improvement. An organization is effective to the degree to which it achieves its goals. An effective organization will make sure that there is a spirit of cooperation and sense of commitment and satisfaction within the sphere of its influence. In order to make employees satisfied and committed to their jobs in academic and research libraries, there is need for strong and effective motivation at the various levels, departments, and sections of the library.

In this research, Job satisfaction has been defined in various ways. Job satisfaction is a combination of cognitive and affective reactions to the differential perceptions of what an employee wants to receive compared to what he or she actually receives (Boyt, Lusch, \& Naylor, 2001). Job satisfaction is an individual's cognitive, affective, and evaluate reactions towards his or her job (Greenberg and Baron, 1997). Job satisfaction is a state where one's needs and one's outcomes match well (Locke, 1976). Job satisfaction is argued to be reaction to one's job emotionally (Kreitner and Kinicki, 1992). Job satisfaction by definition is employee's sense of achievement and success that is directly linked to productivity and personal wellbeing (Islam MF, 2015) 
Nature of Human Resource Management (HRM) practices and Its impact on Employee's Job ..

It is a single idea that could be interpreted only in monetary terms (Lazear, 2000). It has been argued that employees generally appreciate rewards on one hand while on the other hand repugnant effort. Therefore, a better wage/salary for same level of effort, will suggest a decision to quit job with lower wage, which will increase the level of satisfaction. Essentially, there is need to see employment demands beyond the exchange of services for salaries. Though, employment demands are seen as economic relation in nature, but it is important to note that it has a strong affiliation to social and psychological views (Baron and Kreps, 1999). An employee may be satisfied with the monetary rewards and express some level of dissatisfaction with one or two aspects of his employment demands such as managerial policies (Festinger, 1954; Adams, 1965), either because they stand as hurdles to fulfill his needs (Salansik and Pfeffer, 1977) or values (Locke, 1976) or because his expectations were not met by the monetary rewards. Thang and Buyens (2008) stated that training and development lead to superior knowledge, skills, abilities, attitudes, and behavior of employees that ultimately enhance excellent financial and nonfinancial performance of the organizations. Rathnaweera (2010) -The findings of the research revealed that Human Resource Management practices are significant predictors of employee satisfaction, commitment and retention.

Padala (2010) conducted a study to identify the various parameters for employee job satisfaction and organizational commitment. The study showed that employees have a positive inclination in their intensity of commitment towards their organization. Age, education, nature of the job, length of service and income have negative relations with the employee job satisfaction as well as organizational commitment. Employees playing very active participation in trade unions are found to have more job satisfaction and high degree of organizational commitment. Abbas (2011) reported that financial factors, working conditions, supervision and advancement opportunities are associated with the overall satisfaction of the banking professionals Suman Devi and Suneja (2013) stated that significant difference exists between employees of public and private sector banks in various aspects of job satisfaction, pay and fringe benefits, supervision, training and development. But these differences are not significant in case of the aspects, in relation to co-workers, employee's empowerment, supervision, performance appraisal and nature of job.

Majumder (2012) has provided a deep insight on HRM practices and job satisfaction of employees in different private banks of Bangladesh. His finding suggests that most of the employees are dissatisfied with compensation package followed by reward and motivation, career growth, training and development, management style, job design and responsibilities.

Masoodul et al, (2013) used three HRM practices (compensation, empowerment and appraisal system) and their impact on employee's job satisfaction and loyalty. His investigation was carried out on several government owned banks, and the finding that compensation is most crucial for developing employee's job satisfaction; meanwhile empowerment can be considered as a significant factor for employee's loyalty. Hussain and Rehman (2013) studied the relationship between the HRM practices implemented by the organization on employee's willingness to stay and work effectively for the organization. The result of the study explored that HRM practices viz-a-viz: person-organization fit, employment security, communication and training and development are contributing strongly in developing the employees' intentions to stay with organization. Further, strong positive interrelationships were found between HRM practices and employees' retention and such practices enhances employees' retain ability of organizations.

\section{Profile of Dutch-Bangla Bank Limited:}

Dutch-Bangla Bank Limited (the Bank) is a scheduled commercial bank set up as a joint venture between Bangladesh and The Netherlands. The Bank was established under the Bank Companies Act 1991 and incorporated as a public limited company under the Companies Act 1994 in Bangladesh with the primary objective to carry on all kinds of banking business in Bangladesh. The Bank is listed with Dhaka Stock Exchange Limited and Chittagong Stock Exchange Limited.

DBBL- a Bangladesh European private joint venture scheduled commercial bank commenced formal operation from June 3, 1996. The head office of the Bank is located at Senakalyan Bhaban (4th floor), 195, Motijheel C/A, Dhaka, Bangladesh. The Bank commenced its banking business with one branch on 4 July 1995 , with a motto to grow as a leader in the banking arena of Bangladesh through better counseling and effective service to clients and thus to revitalize the economy of the country. The number of branches as till date is 157 .

\section{HRM practices followed by Dutch-Bangla Bank Ltd}

The Bank's Human Resources policies are based on trust and relationship. The Bank's policy is to look after people who want to make a long-term career with the Bank because trust and relationship are built over time. Remuneration package may be an important factor to motivate for joining a company, but it is not the only one. The corporate culture at DBBL as grew over last 20 years is such that the members of the staff have ample opportunities to take initiative and responsibilities to unleash their hidden potential to maximize benefits for themselves and for the society. The challenge is to maintain a business like, committed corporate culture that 
matches DBBL's mission. Achieving results and taking responsibility are important components of the culture we pursue, one in which management and staff work together and are mutually accountable. As DBBL is having a highly technology based work environment, it is one of the basic objectives to build a robust and productive workforce fit for the job. Therefore, training and practical orientation on various disciplines of banking throughout the year continues under HR improvement plan. Motivation process through various means also continues to invigorate the workforce. Special training and workshops including refreshers' training on Anti Money Laundering and Anti-Terrorism are undertaken throughout the year. The Human Resources Department mainly formulate policies and carryout the following activities:

\section{Human Resources Planning of DBBL:}

In common with most organizations, DBBL's performance depends on the quality and commitment of its people. Accordingly, Bank's stated strategy is to attract, retain and motivate the most talented people in the industry. The total number of employees is 5201 at the end of 2015. The corporate culture of DBBL as grew over last 20 years is such that the members of the staff have ample opportunities to take initiative and responsibilities. The challenge is to maintain a business like, committed corporate culture that matches DBBL's mission. Achieving results and taking responsibility are important components of the culture we pursue, one in which management and staff work together and are mutually accountable. Following issues is followed by DBBL for its HR planning:

i) At the beginning of the year HR officials analyzed the business trend of the previous year in connection with Bank's expansion plan for the next year;

ii) Bank's Human Resources Division (HRD) also collects data regarding human resources requirement from all line managers of the Bank;

iii) HR officials also analyze employee turnover ratio of the Bank;

iv) Considering the above, HRD fixes up Bank's required category wise employee with their qualities/ experiences for the coming year;

v) After finalization of employee requirement of the Bank, the matter is placed before Management of the Bank for perusal; and

vi) Finally, employee requirement for the coming year is approved by the Board of Directors.

\section{Recruitment process of DBBL:}

Recruitment is the process through which the organization seeks applicants for potential employment. Selection refers to the process by which it attempts to identify applicants with the necessary knowledge, skills, abilities and other characteristics that will help the company achieve its goals, companies engaging in different strategies need different types and numbers of employees. The strategy a company is pursuing will have a direct impact on the types of employees that it seeks to recruit and selection.

\section{Source of recruitment}

There are two kinds of source DBBL uses for recruitment. They are

1. Internal source

2. External source.

1. Internal source

DBBL thinks that current employees are a major source of recruits for all but entry-level positions. Whether for promotions or for lateral job transfers, internal candidates already know the organization and have detailed information about its products, formal policies and procedures. Promotions and transfer are typically decided by Top Management with involvement of HR department.

\section{External source}

When job requirement cannot be filled internally, the HR department of DBBL look outside the organization for applicants. The most familiar form of employment is advertising. DBBL seek interested people by giving advertisement in daily newspapers. In 2008, DBBL gave three advertisements through daily newspapers. One for experienced and two for fresh entrants (one for general cadre and another for cash cadre.

\section{Nature and class of posts:}

i) Posts under the Bank shall be of two categories: (a) Regular, and (b) Casual.

a) Regular posts are those posts carrying a definite rate of pay and sanctioned without limit of time.

b) Casual posts are created for (a) the performance of duties of a casual (e.g. day to day) or intermittent nature, or (b) the execution of a particular work. 


\section{Nationality:}

No person is appointed to any post in the service of the Bank unless he / she is a citizen of Bangladesh;

Age:

The age of all new recruits at entry point into Bank's service is governed as per following provisions:

a) At the time of appointment to the post of an officer, the age of the candidate shall not be less than 21 (twenty one) and more than 30 (thirty) years; and

b) At the time of appointment to such posts which have not been declared as Officer, the age of the candidate shall not be less than 18 (eighteen) and more than 25 (twenty five) years.

In case of recruitment of experienced personnel age limit is relaxed up to 65 years. In this case, age limit is considered up to 57 years for regular employment as retirement age for regular employee is 57 years.

\section{Physical Fitness:}

No persons shall be appointed in the service of the Bank unless he is declared physically and mentally fit by the Medical Officer of the Bank or any other Medical Authority specified by the Bank in this behalf.

\section{Procedure for recruitment:}

i) All appointments to specified post are made in accordance with the provision of the Bank by:

a) direct recruitment ;

b) promotion ;

c) transfer on deputation ;

d) Contract as specialist / advisor for exceptionally qualified personnel.

ii) Where suitable candidates or adequate number of suitable candidates for promotion against the vacant post (s) are not available from within the Bank's own man-power, the vacant post (s) are filled in by direct recruit.

Fresher graduate are recruited usually for two post, viz. Trainee Officer (TO) and Assistant Officer (AO) through a competitive written examination generally conducted by Institute of Business Administration (IBA) of Dhaka University followed by a viva voce examination undertaken by the Recruitment Committee of the Bank. Out of the existing employees who intends to appear before the recruitment process of any position of fresher entrant shall have to fulfill the criteria set for the post. Their applications are scrutinized as usual for other applicants.

\subsubsection{General Flow Chart of Selection Procedure}

As per recruitment procedure of Dutch-Bangla Bank Limited, Human Resources Division follow the following Flow Chart for recruitment of its manpower:

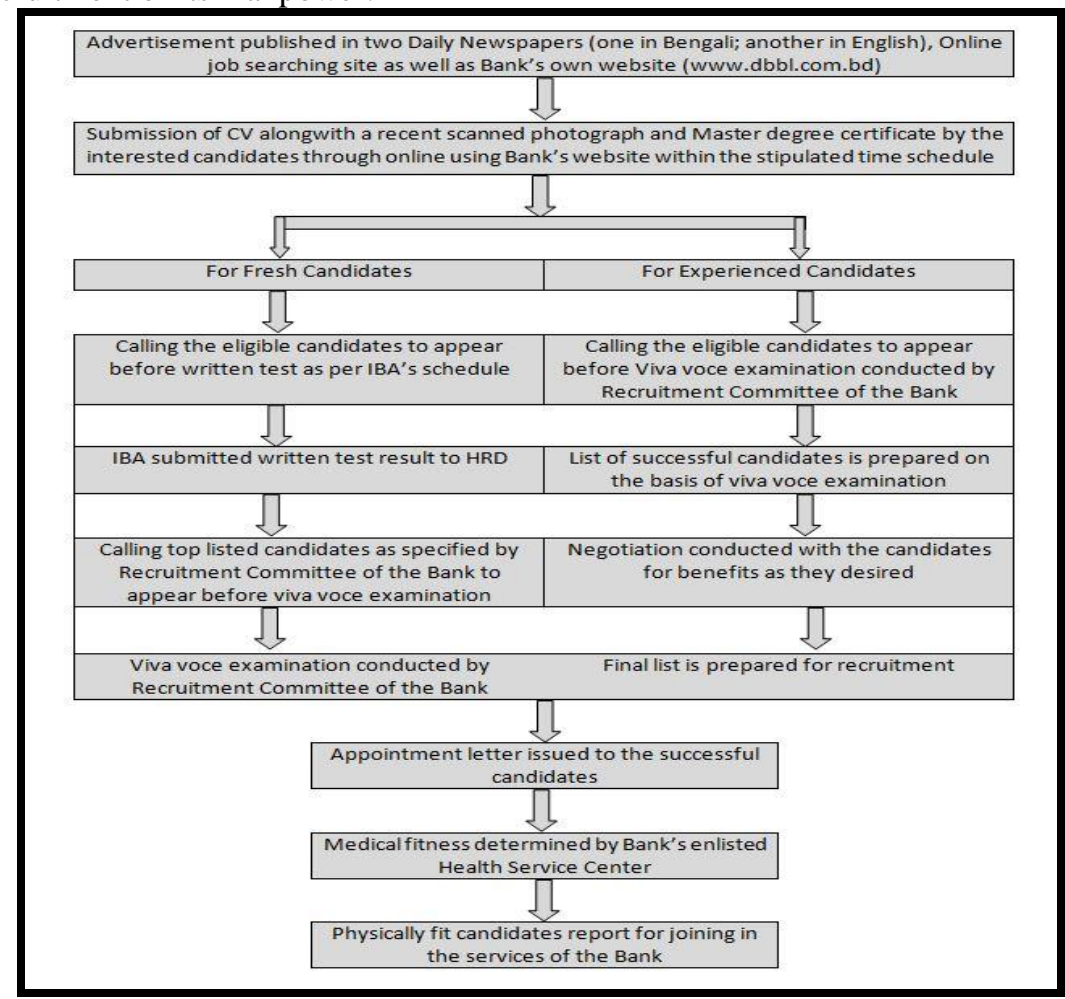


Nature of Human Resource Management (HRM) practices and Its impact on Employee's Job ..

Apart from the above Bank's Human Resources Division maintain a database the CVs which they received time to time internally from different sources. For fulfillment of immediate requirement, Bank recruited personnel directly by conducting a viva voce. In this case, Bank takes help from the database as mentioned above.

\subsubsection{Absorption of Fresh Officer in the Regular Service of the Bank:}

After completion of probationary period, the performance of a fresh officer is evaluated by the Management. In cases, the Management may extend the probationary/ training period. Also antecedence of the officials is verified by law enforcing agency. Obtaining satisfactory report from the law enforcing agency, fresher entrant are absorbed in regular services of the Bank subject to their completion of satisfactory probation period.

\subsubsection{Placement of personnel}

DBBL follows "Right people in right place" concept for placement of their employees. Bank considers employees' living place, educational association, family bonding etc. in case of their placement. Above all, Bank considers its immediate need for placement of officials. However, the competent authority of the Bank has the right to transfer officers and employees of the Bank from one department to another, or from one branch to another branch of the Bank in Bangladesh or out side Bangladesh, unless the terms of employment specifically provide otherwise. If any officer/ employee refuses to comply with any lawful order of transfer by the competent authority, this refusal is treated as misconduct and the authority reserves the right to take disciplinary action against the officer/ employee concerned.

\section{Training of DBBL:}

DBBL attaches utmost importance to the development of its employees through continuous training. DBBL believes in both "on the job" and "off the job" training. It established Training Wing for facilitating in house training program. Besides, Bank's Retail Banking Division, SME Division, Information Technology Division arrange training to introduce new arena of banking to its officials time to time.

A high quality and competent human resource is crucial to continued growth and success of he bank. This can be achieved by improving skill, knowledge and productivity of the employees. As such management of the bank emphasizes training for its employees both in home country and in abroad. My another important task is to arrange training for the employees under the guidance and supervision of my honorable divisional head. There are three categories of training. These are:

a) In-house Training/Workshop/ Seminar

b) External Training/Workshop/Seminar within the country

c) External Training/ Workshop/Seminar in abroad

\section{a. In-house Training/ Workshop/Seminar}

DBBL Training Wing is functioning under the guidance and supervision of Human Resources Division, which organizes various training/ workshop/ seminars for the employees of the bank as per Academic Calendar approved by the management. Broad categories of the training are:

- Foundation Training/ Orientation Training Course (for newly recruited officers)

G General Banking/ Credit/ Foreign Exchange related courses

- Various workshops/ seminars on Banking rules and regulation/ DBBL Asset-Liability products/ Customer Services etc.

Head of Training Wing forwards proposal to Human Resources Division for seeking permission for organizing the program with a request to prepare a list of participants. As being the dealing officer I am assigned to the following tasks:

- Assessment of training needs of the participants after consultation with the records/ Divisional Heads/ Branch Managers.

口 Preparing a list of eligible participants.

Forwarding the file to the competent authority for approval

口 Preparing Office Order with the advice to attend the training program in time.

\section{b. External Training/ Workshop/Seminar within the country}

Different organizations like Bangladesh Institute of Bank Management (BIBM), Bangladesh Bank Training Academy (BBTA), South Asia Enterprise Development Facility (SEDF), peer banks or other financial institutions or other training institutions send invitation for participation of different training/ workshop/ seminar as organized by them time to time. After getting these invitations my activities are as follows:

․ Discuss about the training content with the divisional head 
Prepare list of eligible participant

Send the list to competent authority for approval

After getting approval from the authority, nomination letter is sent to the inviting organization along with course fees (if required) endorsing copies to the concerned Divisional Heads/Branch Managers and concerned trainees.

Liaison with the organizing body of the training program

$\square$ Liaison with the participants and concerned supervisors

\section{c. External Training/ Workshop/Seminar in abroad}

Different International Financial Organizations invite our nomination for attending training program/ seminar/ workshop in abroad. Activities for arranging foreign training/ workshop/ seminar for bank officials are same as arranging external training/ workshop/ seminar. In addition I have to arrange cash allowance (pocket allowance) for the concerned officials.

DBBL training institute organized 18 different training courses and 18 workshops on important banking issues with active participation of 2,158 employees during the year 2015. Apart from the above training programs, the Bank also nominated 300 officials to undergo 161 different training programs/courses organized by different organizations like Bangladesh Institute of Bank Management (BIBM), Bangladesh Bank Training Academy (BBTA) and other similar organizations. Trainings carried out by the Bank's own training institute for the year 2015 are outlined below:

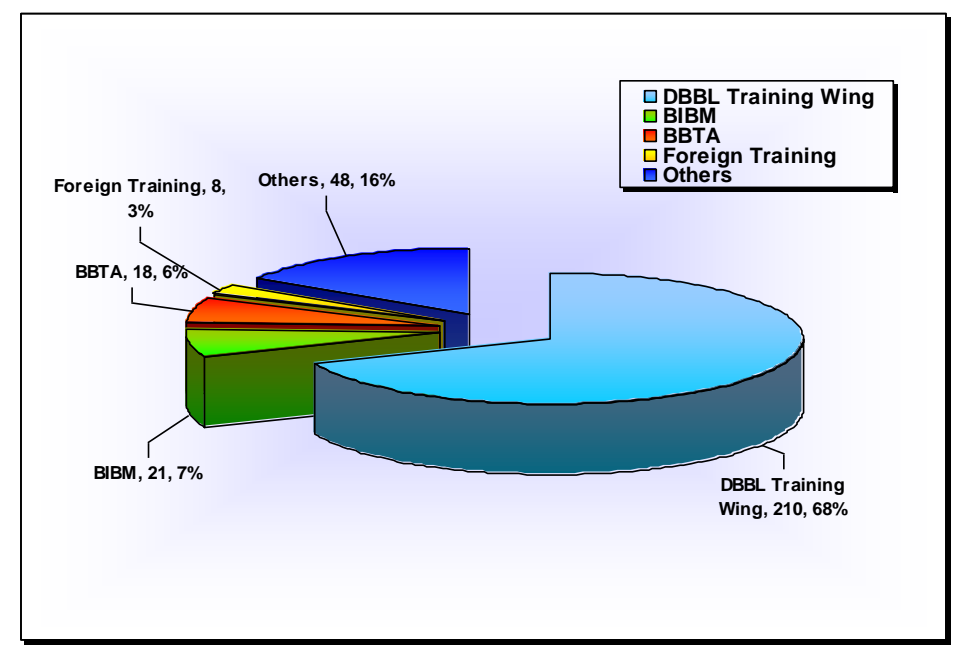

Figure 4.10: Arrangement of training during the year 2015

\begin{tabular}{|c|c|c|c|c|}
\hline $\begin{array}{c}\text { Serial } \\
\text { No }\end{array}$ & \multicolumn{2}{|c|}{ Subject } & $\begin{array}{l}\text { Number of } \\
\text { courses }\end{array}$ & $\begin{array}{l}\text { Number of } \\
\text { Participants }\end{array}$ \\
\hline \multirow[t]{8}{*}{1} & \multicolumn{2}{|c|}{ Training Courses } & & \\
\hline & a & Foundation Training Course & 3 & 117 \\
\hline & b & Credit Risk Management & 2 & 61 \\
\hline & c & International Trade and Foreign Exchange & 2 & 70 \\
\hline & d & Environmental and Social Risk Management Financial Intermediaries & 3 & 124 \\
\hline & e & Newly Recruited Cash Officers (Orientation) & 1 & 51 \\
\hline & $\mathrm{f}$ & Two Factor Authentication (2FA) & 7 & 400 \\
\hline & \multicolumn{2}{|c|}{ Sub-total of training } & 18 & 823 \\
\hline \multirow[t]{6}{*}{2.} & \multicolumn{2}{|c|}{ Workshop } & & \\
\hline & a & Prevention of Money Laundering and Combating Terrorist Financing & 11 & 843 \\
\hline & b & Workshop on Account opening: Procedures and Documentation & 3 & 222 \\
\hline & c & Rules and Benefits' of Export Development Fund & 1 & 21 \\
\hline & d & Integrated Supervision System (ISS) Reporting & 3 & 249 \\
\hline & \multicolumn{2}{|c|}{ Sub-total of workshop } & 18 & 1335 \\
\hline \multicolumn{3}{|c|}{ Ind total of training and workshop } & 36 & 2,158 \\
\hline
\end{tabular}


Nature of Human Resource Management (HRM) practices and Its impact on Employee's Job ..

\section{Motivational Tools of DBBL:}

DBBL always encourages excellence in performance by rewards and recognition. In addition, a number of well thought out policies were formulated for welfare of employees in the form of DBBL Superannuation Fund, DBBL Gratuity Fund, House Building Loan Scheme and Car Loan Scheme etc. In order to ensure better healthcare of employees, there is a medical consultant at Head Office and selective branches to provide medical advices to employees of the Bank. In addition, a thorough medical checkup facility is provided to each employee on a yearly basis.

To strive hard for winning the challenges in a fiercely competitive market, the management has been pursuing the following areas:

To attract and retain best professional in the industry.

J Job evaluation, job enrichment, performance target, performance evaluation, and performance based compensation and incentives.

Evaluating the training need of individual employees including training need for introducing new products, services and technology.

$\square$ Arranging high quality training at home and abroad so that DBBL executives can have competitive advantage in the market.

Encouraging its employees to develop and broaden existing knowledge and skills and to acquire new skills and expertise.

Reviewing and updating organizational structure on a regular basis to have a structure which can give strong support to the strategic objectives of the bank.

DBBL has the following tools to motivate its employees:

\subsubsection{Financial motivational tools:}

i) Salary: DBBL provides attractive remuneration in terms of Basic Pay, House Rent, Medical Allowances and Conveyance to its employee. The competent authority of the Bank recently revised the pay scale for its employee w.e.f. April 01, 2009. Usually, the pay scale is revised in every three years.

ii) Leave Fare Assistance (LFA): DBBL provides @30\% basic pay for each month of a calendar year to each employee as LFA for enjoying leave.

iii) Bonus: DBBL provides festival bonuses, incentive bonus, profit sharing bonus to its employees.

iv) Annual Increment: Employees are given annual increment to cope inflation.

v) Furniture Allowance: The one time benefit as Furniture \& Fixture Allowance for the executives of the Bank is as under:

\begin{tabular}{|l|l|}
\hline Grade & Amount \\
\hline Deputy Managing Director & $5.00 \mathrm{lac}$ \\
\hline Senior Executive Vice President & $4.00 \mathrm{lac}$ \\
\hline Executive Vice President & $4.00 \mathrm{lac}$ \\
\hline Senior Vice President & $2.50 \mathrm{lac}$ \\
\hline First Vice President & $2.00 \mathrm{lac}$ \\
\hline Vice President & $2.00 \mathrm{lac}$ \\
\hline
\end{tabular}

Table 4.8: Furniture Allowances of the executives of Dutch-Bangla Bank Limited

vi) House Building Loan (HBL) facility: Eligible executives (starting from the rank of Assistant Vice President) are provided HBL facility under DBBL Employees' House Building Loan Scheme at a minimum rate of interest, viz. Bank Rate of Bangladesh Bank.

vii) Car facility: Eligible executives (starting from the rank of Assistant Vice President) are provided car facility under DBBL Employees' Car Lease Finance Scheme. Besides, executives starting from the rank Executive Vice President are provided Bank's car.

viii) Provident Fund: DBBL has contributory provident fund facility for its employee as under:

\begin{tabular}{|l|l|}
\hline Own Contribution & $10 \%$ of Basic Salary \\
\hline Bank Contribution & $10 \%$ of Basic Salary \\
\hline Total & $20 \%$ of Basic Salary \\
\hline
\end{tabular}

Table 4.9: Contributory Provident Fund of the employees of Dutch-Bangla Bank Limited

Those Employees who have completed at least 02 (two) years continuous services in the Bank will be eligible for Bank Contribution Provident Fund.

ix) Superannuation Fund: DBBL has superannuation fund facility for its employee as detailed below:

a) Total Fund: 
Nature of Human Resource Management (HRM) practices and Its impact on Employee's Job ..

\begin{tabular}{|l|l|}
\hline Grade & Amount \\
\hline Trainee Officer - Senior Executive Officer & 6 (six) Lac \\
\hline Assistant Vice President - First Vice President & 8 (eight) lac \\
\hline Senior Vice President - Deputy Managing Director & 10 (ten) lac \\
\hline
\end{tabular}

Table 4.10: Superannuation Fund of the employees of Dutch-Bangla Bank Limited

b) Eligibility:

Death Benefits:

$100 \%$ sum assured on death of an employee as per his/ her category during the tenure of service prior to retirement is payable to his/ her nominee and/ or heirs.

Survival Benefits:

\begin{tabular}{|c|c|}
\hline On retirement & $: 50 \%$ of the amount \\
\hline On Resignation & $\begin{array}{l}\text { Continuous services have to be } 05 \text { (five) years } \\
-\quad \text { If eligible; } 05 \% \text { of Survival Benefits; i.e. } 5 \% \text { of } 50 \%=2.5 \% \text { of the amount be paid } \\
\text { to the category of the employee to which he/ she belongs for every year of completed service }\end{array}$ \\
\hline
\end{tabular}

Table 4.11: Survival Benefits of Superannuation Fund of the employees of Dutch-Bangla Bank Limited

b) Non-Eligibility: In case of death by committing suicide

x) Gratuity Fund: DBBL has gratuity fund facility for its employee as detailed below:

\begin{tabular}{|l|l|}
\hline Eligibility Criteria & Amount \\
\hline $\begin{array}{l}\text { On completion of at least 05 (five) years } \\
\text { continuous services in the Bank }\end{array}$ & $\begin{array}{l}- \text { @ } 1 \text { (one) month's Last Basic for every year of completed service; if total } \\
\text { services in the Bank is above 5 years \& less than 10 years } \\
\text { @ @ 2 (two) month's Last Basic for every year of completed service; if total } \\
\text { services in the Bank is above or equal 10 years }\end{array}$ \\
\hline
\end{tabular}

Table 4.12: Gratuity Fund of the employees of Dutch-Bangla Bank Limited

\section{Non-Financial motivational tools:}

i) Work environment: DBBL provides a wonderful work environment to its employee by way of providing modern technology, corporate culture, etc.

ii) Promotion:

$>$ Promotion cannot be claimed as a matter of right;

$>$ Promotion to a higher post shall be made on a temporary basis for a period of one year and on satisfactory performance during this period, the incumbent shall be regularized / confirmed to the promoted position under an order issued by the competent authority;

$>$ In case, an incumbent fails to render satisfactory service during this period, the period of temporary promotion may be extended for a further period of one year, and on expiry of which, the incumbent shall either be confirmed or reverted to the lower post considering his performance;

$>$ Out-of-turn promotion may be given in exceptional cases to an officer / employee for outstanding performance, devotion to duties and for qualifying any professional examination during his services which is a requirement for the higher post.

iii) Leave facility: Employees' of DBBL can avail the following leave though leave is not employees' matter of right:

\begin{tabular}{|l|l|}
\hline Kinds of Leave & Eligibility criteria \\
\hline Earned Leave & $\begin{array}{l}\text { On completion of } 1 \text { (one) year of continuous service in the Bank, unless it is otherwise decided by the } \\
\text { competent authority. All regular employees of the Bank shall earn earned leave on full pay at the rate } \\
\text { of } 1 / 11^{\text {th }} \text { (one-eleventh) of the period of days spent on duty, i.e. 33 (thirty three) days in a calendar year }\end{array}$ \\
\hline Medical Leave & $\begin{array}{l}\text { On completion of 1 (one) year of continuous service in the Bank, unless it is otherwise decided by the } \\
\text { competent authority. }\end{array}$ \\
\hline Extraordinary Leave & On completion of 3 (three) years of continuous service in the Bank. \\
\hline Special Disability Leave & $\begin{array}{l}\text { On completion of 3 (three) years of continuous service in the Bank, unless it is otherwise decided by } \\
\text { the competent authority. }\end{array}$ \\
\hline Quarantine Leave & On joining the service in the Bank. \\
\hline Maternity Leave & On completion of 9 (nine) months of continuous service in the Bank \\
\hline Casual Leave & $\begin{array}{l}\text { On joining the service in the Bank. The total number of days for which casual leave shall be admissible } \\
\text { in a calendar year to an employee shall be 15 (fifteen) day }\end{array}$ \\
\hline Study Leave & On completion of 3 (three) years of continuous service in the Bank. \\
\hline
\end{tabular}

Table 4.13: Different types of leaves for the employees of Dutch-Bangla Bank Limited

iv) Medical facility: DBBL arranges annual medical checkup for its employees for which Bank bears all cost. Bank also executed corporate agreement with some Medical Health Service Providers for conducting medical checkup at a lower cost. 
Nature of Human Resource Management (HRM) practices and Its impact on Employee's Job ..

Performance evaluation method of Dutch-Bangla Bank Limited:

Performance appraisal is the process of assessing employee's past performance, primarily for reward, promotion and staff development purposes. 'Performance appraisal (is) a process that identifies, evaluates and develops employee performance to meet employee and organizational goals. Performance Appraisal doesn't necessarily use to blame or to provide a disciplinary action. Previous management theories used to view performance appraisal as a stick that management has introduced to beat people. Performance appraisals are now more clarified and they concentrate on developing organizational strengths and employee performance.

\section{Performance Appraisal Process:}

As per employment contract, the service of the regular employees of DBBL governs by the rules and regulations contained at the "Dutch-Bangla Bank Employees' Service Rules, 1999", namely service rules of the Bank. Accordingly, the Management of DBBL uses 'Annual Confidential Report (ACR)' method for evaluating performance of its Human Resources. Besides, 'Pyramid Scoring System' method is also used.

\section{Annual Confidential Report Method}

Though this method is generally applied once in a calendar year, it can also be used quarterly, semi-annually under special cases. ACR can be given by the immediate supervisor not ranked below of the employee concerned. And finally, the ACR is countersigned by the immediate superior of the employee concerned. If an employee works several divisions/ branches in a year, in that case ACR should be obtained from those supervisors under whom he/ she works at least 03 (three) months or more. In this case, an average ACR mark is considered for performance appraisal. In ACR, the reporting Supervisor evaluates his fellows in twenty points as detailed below:

i) Intelligence \& mental alertness;

ii) Personality;

iii) Judgment \& sense of proportion;

iv) Initiative and drive;

v) Power of expression;

vi) Ability to perform assigned work;

vii) Discipline;

viii) Perseverance \& devotion to duty;

ix) Ability to implement decision;

x) Tact;

xi) Integrity;

xii) Sense of responsibility;

xiii) Ability to plan organize \& supervise work;

xiv) Capacity of taking independent decision;

xv) Preserve the official record/ documents and maintenance of confidentiality;

xvi) Punctuality;

xvii) Dealing with colleagues \& superior officer;

xviii) Knowledge of rules \& regulations;

xix) Dealing with Bank's client; and

$\mathrm{xx}$ Suitability in the present assignment.

Each and every category as mentioned above is rated numerically giving point as $1,2,3,4 \& 5$. That means highest number an employee can obtain in ACR is 100 .

Besides, the reporting Supervisor or countersigned Supervisor can write general remarks in ACR of an employee.

\section{2. 'Pyramid Scoring System' method}

The competent authority of DBBL has introduced another method namely, Pyramid Scoring System to identify the individual performers of the branches/ divisions of the Bank. This system is mainly designed to determine the efficiency level of the Human Resources of the Bank. It is also used as a tool to the Management to focus on compensation package including the retention of efficient Human Resources as well as training requirement of an employee for his further improvement. The following are the techniques of the Pyramid Scoring System:

By using this system, Branch Manager/ Divisional Heads determine the performance of the employees of the Branch/ Divisions (excluding themselves) by rating from A to D segment of the pyramid where 'A' stands for most outstanding performer and ' $\mathrm{D}$ ' stand for lower level performer. Maximum/ minimum number for the employees excluding Manager/ Divisional Head can be rated and accommodated according to their 
overall performance for each segments from A to D are as mentioned in the pyramid. During calculation of the maximum/ minimum number of employees in a segment, all fractional figures have to be rounded to the integer as per rounding rule of arithmetic.

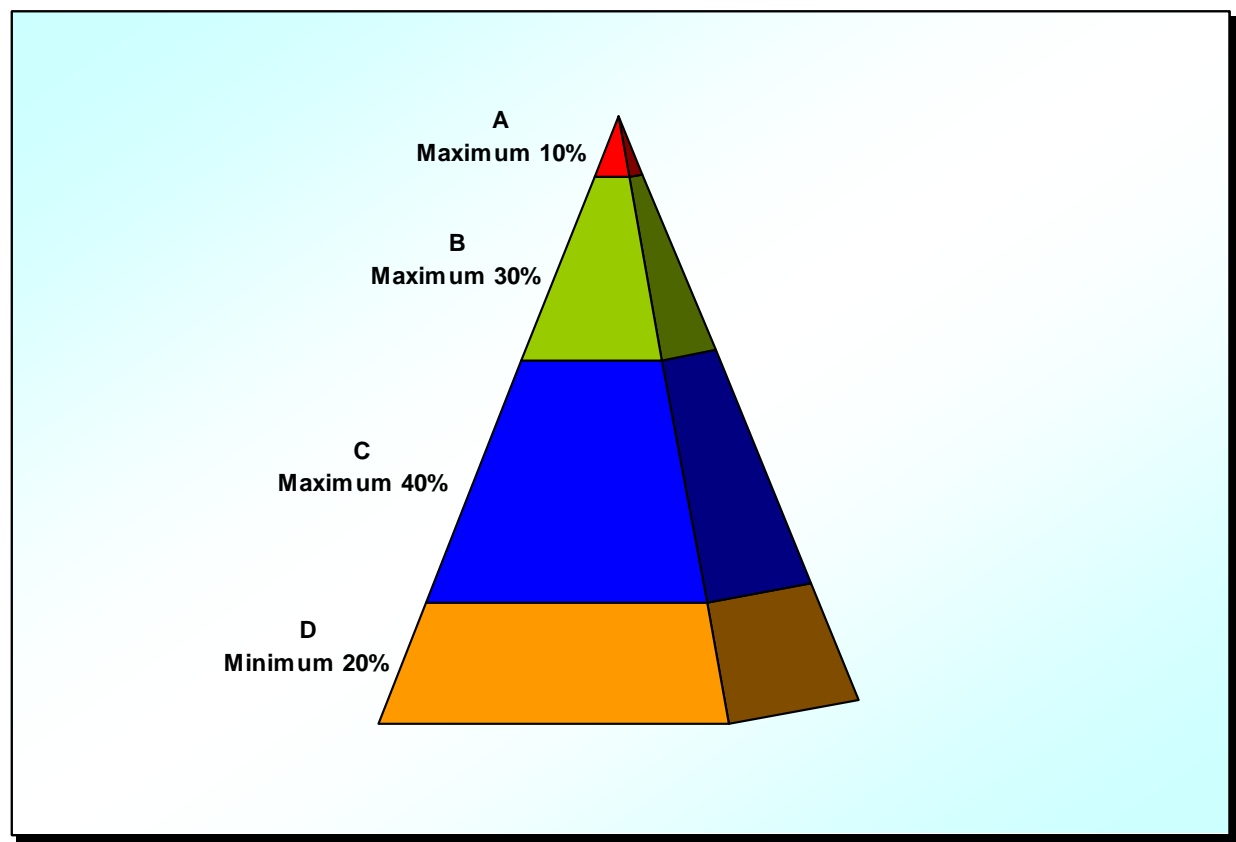

Figure 4.12: 'Pyramid Scoring System' method of Dutch-Bangla Bank Limited

All the employees are categorized numerically as per Pyramid Scoring System as under:

A category employee $=2$

B category employee $=1.5$

C category employee $=1$

D category employee $=0.5$

Number of performance bonus and annual increment is weighted as per abovementioned category.

\section{Managing Transfer and Promotion in DBBL:}

In case of transferring an official to one place to another, DBBL considers employee's living history (where he lived, for what geographical location he is familiar etc.), family bindings etc. Usually, an employee is transferred from one place to another after completing 03 (three) years in a single place of posting. Besides, the Management encourages job rotation practices among the employees. Each and every controlling officer has to submit job description of the employees under their control in every month. The Human Resources Division of the Bank evaluates this statement to evaluate the potentiality of the employees. On the other hand, DBBL has a committee named "Promotion Committee" to evaluate eligibility of the employee to be given promotion to the next higher post. In the regard the following methods are followed:-

1. Call for Promotion Viva:

To determine eligibility for getting call from "Promotion Committee" an employee has to fulfill the following status:

(a) Length of service in DBBL: 2 years as on $31^{\text {st }}$ December of a calendar year

(b) Pyramid Rating Score:

\begin{tabular}{|l|l|l|}
\hline Designation & $\begin{array}{l}\text { Aggregate Pyramid Rating Score (from the last promotion year to } \\
\text { effective promotion year) }\end{array}$ & Remarks \\
\hline TO - SEO & 4 & $\begin{array}{l}\text { Pyramid Rating Score: } \\
\text { A=4, B=3, C=2, D=1 }\end{array}$ \\
\hline AVP - SVP & 5 & P \\
\hline
\end{tabular}

Table 4.14: Pyramid Rating Score for the employees of Dutch-Bangla Bank Limited

Those employees who fulfill the abovementioned criteria are listed for appearing before the "Promotion Committee". 


\section{Performance Indicator:}

The Committee evaluates the performance of the eligible employee in regard to educational qualification, professional qualification, last 2 years ACR marks and Supervisor's comments, deposit target achievement, physical fitness, diversified working experience, write-up on desk job etc.

\section{Selection of employees for Promotion:}

Human Resources Division of DBBL prepares Manpower Budget considering Bank's policy for expansion program as well as business growth. Also the division identifies the number of vacant position for every grade. On the basis of vacancy position in each grade, viva performance and performance indicators of the incumbents, the committee finally selects the employee for giving promotion.

\section{Disciplinary measures for controlling:}

For effective controlling on preventing malpractices by any employees DBBL practices the following issues:

\section{Grounds for punishment:}

a. commits a breach of the provisions of these rules; or

b. displays negligence in the discharge of his duties; or

c. does anything detrimental to the interest and good-will of the Bank; or

d. contravenes instruction issued to him in connection with his assigned official duty; or

e. commits a breach of discipline, or is guilty of any other act of misconduct, desertion or insubordination; or

f. is convicted of any offence involving moral turpitude; or

g. is inefficient, or has ceased to be efficient, whether by reason of infirmity of mind or body; or

h. is guilty of theft, misappropriation, embezzlement or fraud; or

i. $\quad$ is corrupt or may reasonably be considered to be corrupt, because:-

j. he is, or any of his dependents or any other person through him or on his behalf is, in possession (for which he cannot reasonably account) of pecuniary resources or of property disproportionate to his known source of income; or

k. he has assumed a style of living beyond his ostensible means ; or

1. he has a persistent reputation of being corrupt ; or

$\mathrm{m}$. is engaged, or is reasonably suspected of being engaged, in subversive activities or is reasonably suspected of being associated with others engaged in subversive activities, and whose retention in service is considered prejudicial to national security ;

\section{Kinds of penalties:}

There shall be two kinds of penalties which may be imposed under these rules; namely (a) minor penalties \& (b) major penalties.

\section{A. Minor penalties:}

The following are the minor penalties: -

(a) censure ;

(b) withholding, for a specified period, of promotion or of increment otherwise than for unfitness for promotion, or financial advancement;

(c) stoppage, for a specified period, at an efficiency bar in the time-scale of pay, otherwise than for unfitness to cross such bar;

(d) deduction of an amount equivalent to 7 (seven) days substantive pay;

(e) Reduction to a lower stage in the time-scale of pay.

\section{B. Major penalties:}

The following are the major penalties: -

(a) reduction to a lower post or time-scale of pay;

(b) Recovery from pay or any other amount due to the employee of the whole or part of pecuniary loss caused to the Bank by the employee due to negligence or breach of orders.

(c) Removal from the service.

(d) Dismissal from the service.

Note: Removal from service does not, but dismissal from service does, disqualify from future employment under the Bank or its constituents.

\section{Definition of Misconduct:}

(a) insubordination alone, or in combination with others, disobedience to any lawful or reasonable order of superior;

(b) theft, fraud, or dishonesty in connection with the Bank's business or property ; 
Nature of Human Resource Management (HRM) practices and Its impact on Employee's Job ..

(c) damage to or loss of the Bank's goods or property ;

(d) habitual late attendance, habitual leaving from office early, or returning to office late from lunch break ;

(e) absence from duty without obtaining prior permission of the competent authority ;

(f) drunkenness, drug-addiction, gambling, riotous, disorderly or indecent behavior while on duty ;

(g) striking, picketing, or agitation in any form within the Bank premises and in places where it is lawfully prohibited;

(h) illegal striking of work, singly or with others, in contravention of any law or rule for the time being in force, or inciting others to strike ;

(i) holding of meetings or gathering within the Bank premises without the previous permission of the competent authority ;

(j) Refusal to work in another job / post or at any other office or place of the Bank as may be directed by the competent authority in or outside Bangladesh.

(k) habitual indiscipline and leaving of work without permission, disappearance from the seat or place of work without permission during the duty hours ;

(l) unauthorized use of Bank's property ;

(m) malingering, slow-down of work, undue delay in the discharge of duty, refusal or negligence to carry out a official order of the superior ;

(n) habitual negligence to duty

(o) breach of Bank's rules, standing orders or directives and instructions ;

(p) improper and non-use of uniforms, if supplied, while on duty ;

(q) writing anonymous letter, or criticizing the superior or misbehaving with the superiors ;

(r) threatening or intimidating any employee within or outside the Bank premises;

(s) refusal to accept a charge sheet, order or any other communication by the competent authority ;

(t) failure to notify the Competent Authority of change of present address within seven working days ;

(u) failure to inform the leave address before proceeding on authorized leave;

(v) signing of attendance register for another employee or asking another employee to sign his attendance;

(w) Doing personal or private work within the office with or without tools / materials / equipment belonging to the Bank, without the previous written permission of the Head of the Office.

\section{Processing of disciplinary issues:}

When any irregularities observed in the Branches/ Divisions of Head Office, which requires disciplinary action, information is collected regarding the matter from the concerned division/ branch and the matter is consulted with divisional head. After that Internal Control \& Compliance Division is requested for special audit, if feels necessary. According to the audit report/ comments, office note is prepared for the decision of the competent authority. As per decision of the authority, disciplinary actions are taken against the delinquent employee.

\section{GENERAL CONDUCT \& DISCIPLINE:}

\section{Place of Service:}

Every employee shall be required to serve at any office of the Bank including its branches, subsidiaries, affiliates, and associates in such capacity and place, including overseas assignment, as may be directed by the competent authority from time to time.

\section{Observance of Rules \& Directives:}

Every employee shall conform to and abide by these Rules, and shall observe, comply with and obey all lawful orders and directives / directions which may, from time to time, be given by any person or persons under whose jurisdiction, superintendence or control, he may, for the time being be placed from time to time.

Fidelity and Secrecy:

(a) Every employee shall serve the Bank honestly, faithfully, and diligently, and shall maintain strict secrecy regarding the affairs and business of the Bank and its constituents / establishments, and shall not communicate, directly or indirectly to any person any information which has come into his possession in the course of his duties whether from official sources or otherwise, unless directed to do so by the competent authority.

(b) Every employee shall show courtesy and attention in all transaction and to all persons having dealings with the Bank.

Participation in political Activities:

No employee shall, directly or indirectly, take part in, subscribe in aid of or assist in any way, any political movement or associate himself in any activity detrimental to the interest of the Bank or of the state. 
Nature of Human Resource Management (HRM) practices and Its impact on Employee's Job ..

\section{Use of political Influence:}

No employee shall bring or attempt to bring any political or other outside influence to bear on any authority of the Board / competent authority in support of any claim made by him in connection with his employment, increment, promotion or for any other personal gain.

Absence from duty:

No employee shall absent himself from his duties nor leave his station overnight nor extend or overstay the period of any leave sanctioned to him without obtaining prior permission of the competent authority.

\section{Acceptance of Gifts:}

No employee shall accept any gift, gratuity, subscription or reward from any other employee of the Bank or any customer, constituents or persons likely to have dealings with the Bank directly or indirectly, on his own behalf or on behalf of any other person or permit any member of his family to do so.

\section{Acceptance of part-time job:}

Every employee shall be the full-time employee of the Bank and shall not:

a) engage in any commercial business or pursue such business either on his own account or as agent of others;

b) act as an agent of an Insurance company;

c) accept any outside employment, honorary or stipendiary without obtaining prior approval of the competent authority;

d) Undertake part time work except those, which may be requested to be accepted or undertaken by the Board or the competent authority.

\section{Representation to the Board / Directors:}

No employee shall make any personal representation to the Board or to any Director of the Bank. Representation, if any, shall be addressed to the Managing Director, and channeled through the immediate superior of the employee.

\section{Approach to Minister / Member of Parliament:}

No employee shall make any direct approach to any Minister or Member of Parliament or any other non-official / official to intervene on his behalf in any matter of the Bank.

Borrowings:

Every employee shall avoid habitual indebtedness. He shall not borrow money from his associates or subordinates or constituents of the Bank or from any person or persons likely to have dealings with the Bank.

\section{Borrowing from Bank:}

No employee, his wife / her husband, dependent children or other dependent shall raise any loan from the Bank without making proper disclosure of the incident to the competent authority.

14.14: Nepotism, favoritism \& victimization, etc.:

No employee of the Bank shall indulge in parochialism, favoritism, victimization and willful abuse of office or of power and authority.

14.15. Propagation of sectarian creeds, etc.:

No employee of the Bank shall propagate such sectarian creeds or take part in such sectarian controversies or indulge in such sectarian partiality and favoritism as are likely to affect his integrity in the discharge of his duties or to embarrass the administration or create feeling of discontent or displeasure amongst the people in general.

\subsection{Solicitation of employment to other organization:}

An employee of the Bank may apply to other Organization/Institutions for employment only with prior approval of the competent authority. Such employee will have to submit application to the Human Resource Division of the Bank through proper channel with the request to consider its onward transmission to the concerned Organization/Institution.

\subsection{TERMINAL BENEFIT AND COMPENSATION:}

17.1: Kinds of Terminal benefits:

The following kinds of terminal benefits may be admissible to a regular and full-time employee of the Bank:

(a) Gratuity;

(b) Contributory Provident Fund;

(c) Benevolent Fund;

(d) Group Insurance;

(e) Compensatory payment for refused Earned leave;

(f) Superannuation Fund. 
Nature of Human Resource Management (HRM) practices and Its impact on Employee's Job ..

17.2: Gratuity:

Subject to fulfilling the terms and conditions as specified in rule- 12.1, an employee, at the time of retirement or release from the service of the Bank, shall be entitled to Gratuity benefit.

\section{3: Contributory Provident Fund:}

Subject to fulfilling the terms and conditions as specified in rule -13.1 , an employee, at the time of retirement or release from the service of the Bank, shall be entitled Contributory Provident Fund benefit.

17.4: Group Insurance:

17.4.1: Provision of Group Insurance:

If an employee happens to die in the course of his / her service in the Bank, the Bank shall pay to the nominee (s) a sum equal to the employee's 24 (twenty four) months base pay last drawn by him / her, subject to a maximum of Taka $200,000 /=$ (Taka two lacs).

\subsection{2: Arrangement with Insurance Company:}

The Bank may arrange for the "Group Insurance " of the employees in sums mentioned in sub-rule - 17.4.1 here in above with such Insurance Company and for such period as deems fit. The liability to pay the said specified sum shall directly devolve upon the Insurance Company.

\subsection{3: Establishment of Insurance Fund:}

(a) The Bank may establish the "Dutch-Bangla Bank Employee's Insurance Fund" which shall vest in and be held and administered by a committee consisting of three members to be appointed by the Board.

(b) The Group Insurance premium received from the employees shall be credited to the Insurance Fund.

(c) The amount of money as received shall be kept in the Bank. Any interest accrued thereon shall also be credited to this fund

(d) The payment of premium to the Insurance Company shall be made out of this fund.

\subsection{4: Payment of Premium by the employees:}

(a) Every regular employee, covered under the Group Insurance Scheme shall pay a monthly amount equal to $1 \%$ (one percent) of his / her substantive pay or Taka 100/= (Taka one hundred) whichever is less as premium payable to the Insurance Company for the insurance of his / her life. The amount of premium shall be deducted from his / her pay monthly.

(b) where the amount of subscription cannot be deducted from the pay of the employee, the employee shall deposit the sum payable by him to the Bank. If any amount of subscription remains unpaid due to the inadvertence or negligence of the employee, such amount shall be recoverable from him / her in such manner as may be determined by the Board of Trustee.

\subsection{5: Payment of the sum assured:}

(a) On the death of an employee, the Bank shall make a claim for the sum assured under the insurance scheme for him / her to the Insurance Company, and upon reimbursement of the sum, it shall be paid to the nominee (s) in accordance with the instruction in full, or in the shares specified by him / her in the form of nomination.

(b) In the absence of any valid nomination by the employee, the sum assured shall be paid to the legal heir / heirs (as per succession certificate) of the deceased employee.

\section{5: Benevolent Fund:}

17.5.1: The Bank shall establish a Fund to be called "Dutch-Bangla Bank Employee's Benevolent Fund".

17.5.2: Source of Fund:

The fund shall be credited by: -

(a) All sums paid by the employees as subscription to the fund;

(b) All grants/ donation made by the Bank or other Organizations and Institutions or by individuals.

(c) All income profits or interests accruing to the fund or from investment of the fund.

\subsection{3: Investment:}

The amount credited to the Benevolent Fund shall be kept in the Bank or invested in such manner as may be prescribed by the Board of Trustee to be constituted by the Board for management and administration of the Fund.

\subsection{4: Subscription to the fund:}

(a) Every regular employee shall be liable to pay a monthly subscription equal to $1 \%$ (one percent) of his / her substantive pay or Taka 100/= (one hundred) whichever is less. Such subscription shall be deducted from his / her pay monthly.

(b) Where the amount of subscription cannot be deducted from the pay of the employee, the employee shall deposit the sum payable by him / her to the Bank. If any amount of subscription remains unpaid due to 
inadvertence or negligence of the employee, such amount shall be recoverable from him / her in such manner as may be determined by the Board of Trustee.

(c) However, default in the payment of subscription shall not affect his / her right or the right of his / her nominee (s) to receive the benevolent grant as provided in sub-rule 17.5.5; but the amount of the unpaid subscription will be adjusted from the benevolent grant payable to him / her or to his / her nominee (s) in the event of his death during the service.

17.5.5: Payment of benevolent grant:

(a) If an employee is declared completely incapacitated physically or mentally to discharge the official duties and is removed / terminated from service for that reason; or dies during the continuance of his / her employment, then he / she or his / her nominee (s), as the case may be, shall be entitled to receive benevolent grant for an amount equal to his / her 12 (twelve) month's substantive pay last drawn with a maximum of Taka $100,000 /=($ Taka one Lac) whichever is less in lump-sum.

(b) In the absence of any valid nomination made by the employee, the benevolent grant shall be paid to the legal heir / heirs (as per succession certificate) of the deceased employee.

\section{6: Compensatory payment of refused Earned leave:}

(a) A compensatory payment for the period of refused Earned Leave under sub-rule 8.4.3 (d) may be made to a regular and full-time employee of the Bank at the time of his release due to retirement / resignation, or in the event of his death during his service in the Bank to his nominee (s) or legal heir / heirs for a maximum period of twelve months, subject to the availability of unspent earned leave to his credit at the time of retirement / release.

(b) The compensation for the period of such refused earned leave shall be calculated on the basis of the employee's substantive pay last drawn.

\section{7: Board's prerogative to sanction terminal Benefit:}

Notwithstanding anything contained in these rules, the Board shall have the prerogative to accord sanction to any and / or all terminal benefits to an employee who has been released from the employment of the Bank on the following grounds, namely: -

(a) an employee who retires under rule 10.1 or is terminated or is asked to resign the terminal benefit for the period of service he has rendered in the Bank .

(b) an employee who is removed from the services of the Bank on disciplinary ground, the terminal benefit for the period of service he has rendered in the Bank.

(c) an employee who is terminated on account of the abolition of post without alternative or suitable employment in the Bank, terminal benefit for such a period as it deems fit.

\section{8: Suspension of Terminal Benefit:}

If any judicial proceedings instituted by the Bank on any departmental proceedings are pending against an employee at the time of his retirement, or ceasing to be in service, as the case may be, he shall not be entitled to any terminal benefits, except his own subscription to any fund and the accrued interest there on till the determination of such proceedings, and the payment to him of any terminal benefit shall be subject to the findings in such proceedings.

\section{Analysis and Discussion}

Impact of Human Resource Management Practices on Job Satisfaction Questionnaire Analysis

\begin{tabular}{|c|c|c|c|c|c|c|c|}
\hline Q no & Question & $\begin{array}{l}\text { No of } \\
\text { RESP }\end{array}$ & $\begin{array}{l}\text { Strongly } \\
\text { agree }\end{array}$ & Agree & Neutral & Disagree & $\begin{array}{l}\text { Strongly } \\
\text { disagree }\end{array}$ \\
\hline 1 & $\begin{array}{l}\text { The organization has fair recruitment and } \\
\text { selection process }\end{array}$ & 60 & 35 & 10 & 5 & 5 & 5 \\
\hline 2 & Compensations are satisfactory & 60 & 10 & 5 & 0 & 5 & 40 \\
\hline 3 & Transfer decisions are fair and effective & 60 & 30 & 10 & 5 & 5 & 10 \\
\hline 4 & $\begin{array}{l}\text { Promotions held on the basis of } \\
\text { Performance appraisal }\end{array}$ & 60 & 35 & 10 & 5 & 5 & 5 \\
\hline 5 & $\begin{array}{l}\text { Management does an excellent job of } \\
\text { Communicating system }\end{array}$ & 60 & 25 & 10 & 5 & 15 & 5 \\
\hline 6 & $\begin{array}{l}\text { Management is disciplined with employee } \\
\text { performance feedback and appraisals. }\end{array}$ & 60 & 30 & 10 & 5 & 10 & 5 \\
\hline 7 & $\begin{array}{l}\text { Employee Socialization \& induction } \\
\text { facilities are suitable }\end{array}$ & 60 & 30 & 15 & 5 & 5 & 5 \\
\hline 8 & Having enough Safety \& Health measure & 60 & 30 & 15 & 5 & 5 & 5 \\
\hline 9 & Having proper Record Maintenance & 60 & 30 & 20 & 0 & 10 & 0 \\
\hline 10 & $\begin{array}{l}\text { Management is quick to deal with problem } \\
\text { employees/performance }\end{array}$ & 60 & 30 & 10 & 5 & 10 & 5 \\
\hline 11 & Having $\quad$ Sound Career Planning \& & 60 & 30 & 10 & 10 & 5 & 5 \\
\hline
\end{tabular}

DOI: $10.9790 / 487 X-1903035572$

www.iosrjournals.org 
Nature of Human Resource Management (HRM) practices and Its impact on Employee's Job ..

\begin{tabular}{|c|c|c|c|c|c|c|c|}
\hline & Development & & & & & & \\
\hline 12 & Discipline measures are satisfactory & 60 & 25 & 15 & 10 & 5 & 5 \\
\hline 13 & $\begin{array}{l}\text { Enough Training and development } \\
\text { opportunity }\end{array}$ & 60 & 25 & 15 & 10 & 5 & 5 \\
\hline 14 & Doing HR Research & 60 & 5 & 5 & 0 & 15 & 35 \\
\hline 15 & Satisfactory leave provisions & 60 & 5 & 5 & 0 & 15 & 35 \\
\hline
\end{tabular}

According to Question 1, The organization has fair recruitment and selection I found that out of 60 respondents, 35 respondents were Strongly agreed, 10 respondents Agreed, 5 respondents were remained Neutral, 5 respondents were Disagreed and 5 respondents were strongly disagreed. As like question 1, all the question's responses were showed in above table.

\section{Recommendations}

Dutch-Bangla Bank Limited needs to exercise scientific method for its manpower planning.

Appropriate job analysis is required immediately.

$\square$ DBBL's recruitment and selection procedure is quite transparent. But more business graduates need to be recruited to handle today's business complicacy.

$\square \quad$ In DBBL employees are satisfied but not highly motivated to perform at their best. So, DBBL should introduce intensive motivational programs for its employees, so that they can enhance their performance.

$\square$ DBBL provides the modern technology and enters truly on One-Line Banking and also provides ATM facility for the customer service. But its Human Resources Division does not use dedicated software for managing its manpower. Thus, they should use special software.

DBBL needs to introduce counseling process to motivate its employees.

$\square$ Need based training method is needed to be incorporated in Human Resources Management system of Dutch-Bangla Bank Limited.

口 In case of placement of employees, Human Resources Division should give emphasis on socio cultural factors of the place of posting as well as employees' family bonding, living status etc.

- DBBL should introduce more financial \& non-financial motivational tools as motivational factors to reduce turnover rate.

I It is urgently needed to open a dedicated cell to handle employees' disciplinary issues to reduce operational risks.

\section{Conclusion}

The successful operation of a bank largely depends on the intellectual progress of the employees. Along with these progress of the employees, technical infrastructures also must be ensured to increase as some good outcomes of effectiveness of the employee and the bank. Generally, the banking profession in Bangladesh is recognized and challenging because of the standardized salary scale, higher social status and self-esteem. At the end of the analysis it can be said that, human resources in banks were enjoying comparatively better facilities under the rules of banking sector. Employees of the bank receiving good number of bonus, compensation, including salary grade, leave facilities, housing facilities, gratuities, provident funds, and losses of accident or death of employees etc. The most of the employees of DBBL are more satisfied with their salary scale, job position, promotion scheme, working environment but very worried about working hours and work pressure. Few of them are less satisfied with HRM polices and practice, job analysis, IT facilities, job evaluation and performance measurement technique. The proper empowerment of DBBL HR department has to consider for preparing management policies, plan and program, forecasting HR demand and supply of human resources and in policy formulation and implementation. This will help to recruit and maintain skilled, knowledgeable and well performed workforce to meet current and future organizational as well as individual needs.

\section{References}

[1]. Afroj, S. (2012). Ongoing Corporate Human Resource Management Practice in Banking sector of Bangladesh. Global Journal of Management and Business Research, 12(2).

[2]. Adams, J.S. (1965). "Inequity in social exchange", in Berkowitz, L. (Ed.), Advances in Experimental Social Psychology, Vol. 2, Academic Press, New York, NY, p. 267-99

[3]. Armstrong M (2006). A Handbook of Personnel Management Practice, 6th edn, Kogan Page, London

[4]. Barrows, D. \& Wesson, T. (2000). "A Comparative Analysis of Job Satisfaction Among public and private sector professionals", The Innovation Journal 5(1)

[5]. Bedamine, J. (2004). Human Resource Management, New York, NY, Mc-Graw Hill.

[6]. Boyt, T., Lusch, R., \& Naylor, G., (2001). "The Role of Professionalism in Determining Job Satisfaction in Professional Services: A Study of Marketing Researchers", Journal of Service Research, 3(4):321-330

[7]. Festinger, L. (1954). "A theory of social comparison processes", Human Relations, Vol. 7, p. 117-40.

[8]. Greenberg, J. \& Baron, R. A. (1997). Behaviour in organizations: Understanding and managing the Human side of work, 6th ed, Prentice-Hall, New Jersey

[9]. Hackman, J. R. \& Oldham, G. R (1975). Development of the job diagnostic survey. Journal of Applied Psychology, 60, 159-170 
[10]. Huselid, M. A., Jackson, S. E., Schuler, R. S. (1997). Technical and strategic human resource management effectiveness as determinants of firm performance, Academy of Management Journal, 39, p. 949 - 69.

[11]. Islam, M.F. (2015), “Job Dissatisfaction of Bangladeshi Garment Workers: Identification of Causes \& Remedies, Stamford Journal of Economics, Vol.2(1), pp.114-127

[12]. Kreitner and A. Kinicki, Organizational Behavior, (1992), Homewood, IL: Richard D, Irwin: Inc.

[13]. Laursen, K., Foss, N. (2003). New human resource management practices, complementarities and the impact on innovation performance, Cambridge Journal of Economics, 27, p. $243-63$

[14]. Locke, E.A. (1976), "The nature and causes of job satisfaction", in Dunnette, M.C. (Ed.), Handbook of Industrial and Organizational Psychology, Sage, Beverly Hills, CA, p. 1297- 349.

[15]. Lazear, E.P. (2000), "The power of incentives”, The American Economic Review, Vol. 90 No. 2, p. $410-15$.

[16]. Marchington, M., Zagelmeyer, S. (2005). Foreword: linking HRM and performance - a never-ending search? Human Resource Management Journal, 15(4), p. $3-8$

[17]. Majumder, M. T. H. (2012). Human resource management practices and employees' satisfaction towards private banking sector in Bangladesh. International Review of Management and Marketing, 2(1), 52.

[18]. Masoodul . H, Saad.H, Muhammad, F.K and Ashar.I (2013).Impact of HR Practices on Employee Satisfaction and Employee Loyalty: An Empirical Study of Government Owned Public Sector Banks of Pakistan. Middle-East Journal of Scientific Research $16(1): 01-08$.

[19]. O.A.osibanjo,O.J.Kehinde.A.J.Abiodun (2012) Human Resource Management and Employee Job Satisfaction: Evidence from the Nigerian Banking Industry. Journal of Economics and Business Research. PP 17-32

[20]. Padala,(2010), "Employees' Job Satisfactions and Organisational Commitment in Nagarjuna Fertilizers and Chemicals Limited, India",Journal of Research in International Business and Management Vol. 1(1) pp. 017-027.

[21]. Storey, J. (1989). From personnel management to human resource management, in Storey, J (ed) New Perspectives on Human Resource Management, Routledge, London

[22]. Steijn, B. (2002). HRM and job satisfaction in the Dutch public sector. Paper presented at the EGPA-Conference in Potsdam, study group on Public Personnel Policies.

[23]. Salansik, G., Pfeffer, J. (1977), “An examination of need satisfaction models of job attitudes", Administrative Science Quarterly, Vol. 22, No. 3, p. 427-39.

[24]. Suman Devi and Suneja, Ajay (2013) Job satisfaction among bank employees: A comparative study of public sector and private sector banks. International Journal of Research in Management and Technology. Vol. 1, No.2.

[25]. Thang, N. N., and Buyens, D. (2008), What We Know about Relationship between Training and Firm Performance: A Review of Literature. Paper Presented at The 7th International Conference on Ethics And Quality of Work-Life for Sustainable Development, Bangkok, Thailand

[26]. Ulrich D., Lake, D. (1990), Organisational Capability: Competing from inside out, New York: John Wiley \& Sons. 